\begin{tabular}{|c|c|c|}
\hline ב & International Journal of Current Research in & \\
\hline & Biosciences and Plant Biology & $\div 23^{\circ}$ \\
\hline $\begin{array}{l}\text { EXCELLENT } \\
\text { PUBLISHERS } \\
\end{array}$ & $\begin{array}{c}\text { ISSN: 2349-8080 (Online) • Volume } 3 \bullet \text { Number } 5 \text { (May-2016) } \\
\text { Journal homepage: www.ijcrbp.com }\end{array}$ & \\
\hline
\end{tabular}

\title{
Cost Effective Techniques for In Vitro Propagation of Two Varieties of Sugarcane
}

\author{
R. A. Sawant ${ }^{1 *}$ and N.T. Meti² \\ ${ }^{1}$ Tissue Culture Section, Vasantdada Sugar Institute, Manjari (Bk), Pune-412 307, Maharashtra, India \\ 2Departemt of Biotechnology, Rajiv Gandhi Institute of IT and Biotechnology, Bharthi Vidyapeeth Deemed University, \\ Pune-411 o3o, Maharashtra, India \\ *Corresponding author.
}

\begin{abstract}
The present study was carried out to optimize cost effective in vitro protocol for mass propagation of two commercial sugarcane varieties grown in Maharashtra, India. The effect of different cytokinins and auxins on in vitro initiation, multiplication and rooting was investigated in sugarcane (Saccharum spp.) varieties; Co86032 and CoC671. Shoot tip explants comprising of apical meristems and 1-2 leaf primordia were carefully excised from the apical region and inoculated on MS basal liquid medium supplemented with different concentrations and combinations of Kinetin and BAP. Only initiation medium was sterilized by autoclaving and further shoot multiplication, rooting was done on medium sterilized with sodium hypochlorite $(4 \% \mathrm{w} / \mathrm{v}$ available chlorine) at the concentrations $0.05 \%$ corresponding to total active chlorine concentration $0.002 \%$ in the medium. With regard to shoot initiation, variety Co86032 showed maximum shoot formation $(96.67 \%)$ on MS medium supplemented with BAP $(0.2 \mathrm{mg} / \mathrm{L})$ and Kinetin $(0.1 \mathrm{mg} / \mathrm{L})$ with $3 \%$ sucrose and $10 \% \mathrm{CW}$ on the other hand variety CoC671 showed maximum shoot formation (93.33\%) on MS medium supplemented with only Kinetin( $0.5 \mathrm{mg} / \mathrm{L}), 3 \%$ sucrose, $10 \% \mathrm{CW}$. The best response in terms of shoot multiplication for variety Co86032 was observed on MS medium with BAP $(0.2 \mathrm{mg} / \mathrm{L})$ and Kinetin $(0.1 \mathrm{mg} / \mathrm{L})$ with $3 \%$ commercial sugar while for variety CoC671 it was observed on MS medium with Kinetin and BAP $(0.2 \mathrm{mg} / \mathrm{L}$ each) and $3.0 \%$ commercial sugar. Variety Co86032 produced multiple shoots with an average number of $31.25 \pm 0.99$ shoots per bottle while variety CoC671 produced $27.72 \pm 0.66$ shoots per bottle. For rooting, the multiplying shoots were separated in smaller groups and transferred on half strength MS liquid medium containing different concentrations of NAA or IBA with different concentrations of commercial sugar. Half strength MS basal medium with NAA (5.0 $\mathrm{mg} / \mathrm{L}$ ) and $5.0 \%$ commercial sugar induced highest rooting $(84.44 \%)$ with average root number per shoot of $8.49 \pm 0.25$ in Co86032. In variety CoC671, half strength MS basal medium with IBA $(5.0 \mathrm{mg} / \mathrm{L})$ and $5.0 \%$ commercial sugar induced highest rooting $(82.22 \%)$ with average root number per shoot of $6.72 \pm 0.48$. The use of commercial sugar can effectively replace the use of expensive sucrose in in vitro multiplication of sugarcane varieties. All culture media were used in liquid state instead of semisolid agar media. Rooted shoots were transplanted in green house for hardening. Use of liquid media, chemical sterilant Sodium hypochlorite $(\mathrm{NaOCl})$ and commercial sugar helped in reducing the cost per plantlet to a considerable extent.
\end{abstract}

Abbreviations: BAP-6-Benzylaminopurine; Kin-Kinetin; NAA-Naphthalene acetic acid; IBA- Indole butyric acid; MS -Murashige and Skoog; PGR-Plant growth regulator; CW-Coconut water. 


\section{Introduction}

Sugarcane (Saccharum officinarum) is a monocotyledonous perennial crop. It has chromosome number of $2 n=80$ (Anita et al., 2000). It is one of the major cash crops grown extensively all over the world. Sugarcane contributes nearly $70 \%$ of global annual sugar production (Sengar, 2010). India is the second largest producer of sugarcane next to Brazil. During 2014-15 the total sugarcane area in India was 5.144 million ha; sugarcane production 359.330 million tonnes and 538 sugar mills produced 28.313 million tonnes of sugar (Anonymous, 2015).

The sugarcane productivity largely depends on the availability of quality seed material, varieties, soil health and farming practices. In sugarcane conventional propagation is through sets which is slow having multiplication ratio of 1:10 per year. Development and release of a new variety of sugarcane for commercial cultivation takes about ten years which is a very long duration (Krishnamurthy, 1994). Lack of rapid multiplication has been a serious problem in sugarcane breeding (Ali and Afghan, 2001). Use of tissue culture technology for rapid multiplication of sugarcane has been emphasized in recent years. Micropropagation technique offers an opportunity for obtaining the best quality planting material in a comparatively shorter period of time (Hendre et al., 1983; Sreenivasan and Sreenivasan, 1992; Tiwari et al., 2011). This technique has now emerged as a powerful tool to accelerate the seed multiplication programme in sugarcane, especially of the newly released varieties. Several protocols were reported for in vitro multiplication of sugarcane (Shukla et al., 1994; Pawar et al., 2002; Ali et al., 2008; Yadav et al., 2012). The previous reports indicate that the hormonal requirements for in vitro morphogenetic responses vary from cultivar to cultivar in sugarcane. Therefore present study was conducted to optimize cost effective in vitro protocol for mass propagation of two sugarcane varieties Co86032 and CoC671.

\section{Materials and methods}

Healthy tops of two sugarcane varieties Co86032 and CoC671 were collected from four to five months old seed crop growing at the research farm of Vasantdada Sugar Institute, Pune. Approximately $8-10 \mathrm{~cm}$ long spindle segments were dissected out after removing all the mature leaves and 2-3 outer leaf sheaths. They were surface sterilized with $0.1 \%$ mercury chloride $\left(\mathrm{HgCl}_{2}\right)$ solution and were given three changes of sterile distilled water to get rid of traces of mercury chloride. The apical meristems were carefully excised from the sterile segment and inoculated on liquid MS (Murashige and Skoog, 1962) media supplemented with different concentrations of BAP and Kinetin alone or in combinations for shoot induction. The sucrose concentration (3\%) and coconut water (10\%) was used and $\mathrm{P}_{\mathrm{H}}$ of medium was adjusted to5.8 and autoclaved at $121^{\circ} \mathrm{C}$ and $15 \mathrm{psi}$ for 15 minutes. Cultures were incubated at $25 \pm 2^{\circ} \mathrm{C}$ under $12 \mathrm{hrs} \mathrm{light}$ and $12 \mathrm{hrs}$ dark photoperiod under fluorescent light having 2500 lux intensity.

After 4-5 weeks of shoot growth, actively growing shoots (meristems) were transferred to bottle containing MS medium with cytokinins; BAP $(0.2 \mathrm{mg} / \mathrm{L})$ and Kinetin $(0.1 \mathrm{mg} / \mathrm{L})$ and were subcultured at 15 days interval to obtain shoot multiplication. These shoot bunches were further subdivided in groups of 3-4 shoots and were transferred on MS multiplication medium bottle containing different concentrations and combinations of BAP and kinetin with $3 \%$ commercial sugar. Before in vitro rooting, the multiplied shoots were transferred on plant growth regulators free MS basal medium for two weeks. Regenerated shoots were transferred to half strength of liquid MS medium supplemented with different concentrations of individual NAA or IBA with varying concentrations of commercial sugar for root induction. Both shoot multiplication and rooting media were sterilized with sodium hypochlorite ( $4 \% \mathrm{w} / \mathrm{v}$ available chlorine) at the concentrations $0.05 \%$ corresponding to total active chlorine concentration $0.002 \%$ in the medium (Sawant et al., 2011). Data in case of shoot initiation were recorded 21 days after inoculation, for shoot multiplication 24 and 30 days for rooting after inoculation. Each individual experiment had three replications with ten samples each. Data were subjected to analysis of variance (ANOVA) using SPSS statistical software. Statistical significance was computed at $p=0.05$ and treatment mean separation was done using procedure of Duncan's new multiple range test.

\section{Results and discussion}

Combined effect of kinetin and BAP on shoot proliferation from apical meristems in sugarcane variety Co86032 and CoC671

It could be seen from the Table 1 that for both varieties, the lowest shoot initiation response was recorded when apical meristems were inoculated on MS medium lacking the plant growth regulators. Among the different 
concentrations and combinations of BAP and kinetin tested, sugarcane variety Co86032 gave the highest (96.67\%) shoot formation response on MS medium supplemented with BAP $(0.2 \mathrm{mg} / \mathrm{L})$ and kinetin $(0.1 \mathrm{mg} / \mathrm{L})$.CoC 671 gave the highest $(93.33 \%)$ shoot formation response on MS medium supplemented with kinetin $(0.5 \mathrm{mg} / \mathrm{L})$. Thus there was differential response of Co86032 and CoC671 varieties to shoot initiation medium.
Similarly increase in the concentration of kinetin $(0.5 \mathrm{mg} / \mathrm{L})$ with BAP $(0.2 \mathrm{mg} / \mathrm{L})$ significantly decreased the frequency of shoot formation and shoot length in variety Co86032. Also in variety CoC671; increase in the concentration of BAP $(0.5 \mathrm{mg} / \mathrm{L})$ with kinetin $(0.5 \mathrm{mg} / \mathrm{L})$ significantly decreased the frequency of shoot formation. Medium containing BAP and kinetin $(0.5 \mathrm{mg} / \mathrm{L}$ each) gave the lowest response of shoot initiation in both the varieties than other combinations of BAP and kinetin tested.

Table 1. Combined effect of Kinetin and BAP on shoot proliferation from apical meristems in sugarcane variety Co86032 and CoC671.

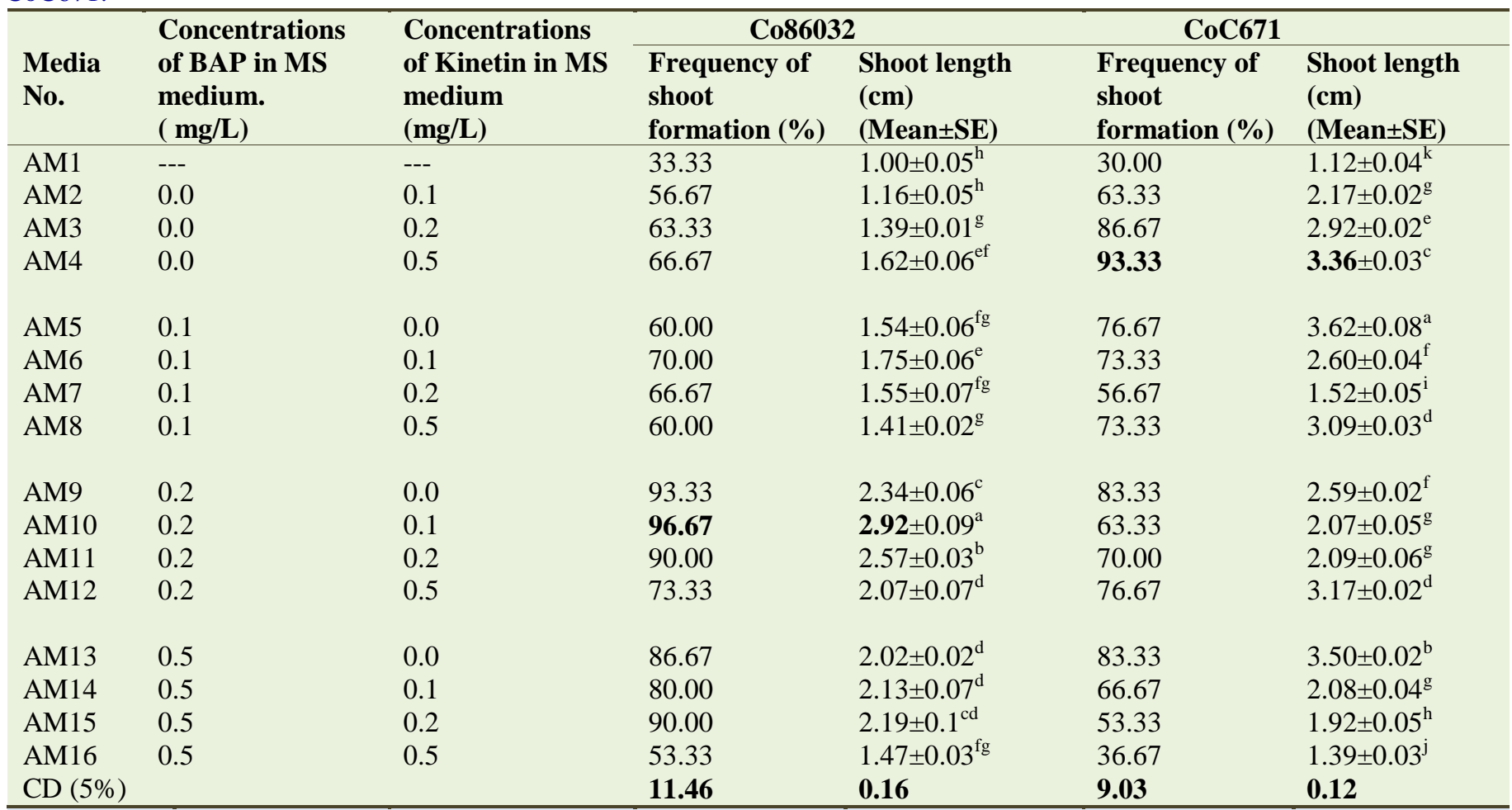

Means followed by different letters in the same column differ significantly at $p=0.05$ according to Duncan's multiple range test.

\section{Effect of kinetin and BAP with $3 \%$ commercial sugar on in vitro shoot multiplication in sugarcane variety Co86032 and CoC671}

After 4-5 weeks of shoot growth, actively growing shoots (meristems) were transferred to bottle containing MS medium with cytokinins; BAP $(0.2 \mathrm{mg} / \mathrm{L})$ and kinetin $(0.1 \mathrm{mg} / \mathrm{L})$ to obtain shoot multiplication. These shoot bunches were further subdivided in groups of 3-4 shoots and were transferred on MS multiplication medium bottle containing different concentrations and combinations of BAP and kinetin with $3 \%$ commercial sugar. It could be seen from the Table 2 that use of kinetin $(0.2$ $\mathrm{mg} / \mathrm{L}$ ) without BAP produced 22.59 shoots per bottle while BAP $(0.2 \mathrm{mg} / \mathrm{L})$ without kinetin produced 27.83 shoots per bottle in variety Co86032; which was significantly improved to 35.96 shoots in the media containing both BAP and kinetin $(0.2 \mathrm{mg} / \mathrm{L})$. Though the shoot number was highest but vigour and shoot length was not good. In the treatment containing BAP $(0.2 \mathrm{mg} / \mathrm{L})$ and kinetin $(0.1 \mathrm{mg} / \mathrm{L})$ produced 31.25 shoots per bottle with good shoot length $(4.45 \mathrm{~cm})$ and quality well grown easily separable and healthy plantlets. The shoots were taller in length in the medium containing kinetin alone but number (multiplication) was less. Similar trend was observed in variety CoC671. Highest 27.72 shoots per bottle were recorded in CoC671 on medium containing both BAP and kinetin $(0.2 \mathrm{mg} / \mathrm{L})$ with shoot length $(4.36$ 
$\mathrm{cm})$. This showed the importance of including BAP along with kinetin in shoot multiplication medium. It indicates that importance of cytokinins (BAP and kinetin) in in vitro multiplication of sugarcane.

Similar results were recorded in vitro sugarcane multiplication by Ali et al. (2008) who reported that best shoot initiation was obtained in the MS medium supplemented with BAP $(0.5 \mathrm{mg} / \mathrm{L})$ and kinetin $(0.25$ $\mathrm{mg} / \mathrm{L}$ ) for sugarcane variety BL-4. Khan et al. (2009) found maximum shoots per explants on MS medium supplemented with BAP $(1.0 \mathrm{mg} / \mathrm{L})$ and kinetin $(0.5$ $\mathrm{mg} / \mathrm{L}$ ) in sugarcane variety CP-77-400 and HSP-240. Hendre et al. (1983) obtained shoots of sugarcane cultivars on different BAP and Kinetin concentrations, while Cheema and Hussain (2004) observed 29 shoots per plant at $0.4 \mathrm{mg} / \mathrm{l} \mathrm{BAP}$ in combination with $0.4 \mathrm{mg} / \mathrm{l}$ Kin. Mekonnen et al. (2014) reported MS medium supplemented with $4 \%$ table sugar, BAP $(2 \mathrm{mg} / \mathrm{L})+$ kinetin $(0.25 \mathrm{mg} / \mathrm{L})$ was found best for shoot multiplication of genotype Co 449 while BAP $(2 \mathrm{mg} / \mathrm{L})$ + kinetin $(0.50 \mathrm{mg} / \mathrm{L})$ was the optimum combination for shoot multiplication of genotype Co678. This strongly supports the use of cytokinin for multiple shoot formation but in the present study low levels of cytokinins gave good results. Similarly low percentage of commercial sugar was used in the present study (3\%). Singh et al. (2006) also reported use of phytohormone combinations for micropropagation of different sugarcane varieties.

Table 2. Effect of kinetin and BAP with $3 \%$ commercial sugar on in vitro shoot multiplication in sugarcane varieties Co86032 and CoC671.

\begin{tabular}{|c|c|c|c|c|c|c|c|}
\hline \multirow{2}{*}{$\begin{array}{l}\text { Sr. } \\
\text { No. }\end{array}$} & \multirow{2}{*}{$\begin{array}{c}\text { MS+PGR } \\
(\mathrm{mg} / \mathrm{l})\end{array}$} & \multicolumn{3}{|l|}{ Co86032 } & \multicolumn{3}{|l|}{ CoC671 } \\
\hline & & $\begin{array}{l}\text { No. of } \\
\text { shoots/bottle }\end{array}$ & $\begin{array}{l}\text { Shoot length } \\
(\mathrm{cm})\end{array}$ & $\begin{array}{l}\text { Shoot } \\
\text { vigour }\end{array}$ & $\begin{array}{l}\text { No. of } \\
\text { shoots/bottle }\end{array}$ & $\begin{array}{l}\text { Shoot length } \\
(\mathrm{cm})\end{array}$ & $\begin{array}{l}\text { Shoot } \\
\text { vigour }\end{array}$ \\
\hline $\mathrm{S} 2$ & $\mathrm{BAP}(0.2)$ & $27.83 \pm 1.26^{\mathrm{c}}$ & $3.51 \pm 0.09^{c}$ & ++ & $21.04 \pm 0.72^{\mathrm{c}}$ & $2.96 \pm 0.23^{b}$ & ++ \\
\hline S3 & $\operatorname{Kin}(0.2)+\mathrm{BAP}(0.2)$ & $35.96 \pm 1.55^{\mathrm{a}}$ & $3.19 \pm 0.03^{\mathrm{cd}}$ & ++ & $27.72 \pm 0.66^{a}$ & $4.36 \pm 0.07^{\mathrm{a}}$ & +++ \\
\hline S5 & $\operatorname{Kin}(0.2)+\mathrm{BAP}(0.4)$ & $26.97 \pm 0.48^{c}$ & $3.00 \pm 0.16^{\mathrm{d}}$ & + & $19.87 \pm 0.55^{\mathrm{c}}$ & $3.34 \pm 0.15^{\mathrm{b}}$ & + \\
\hline $\mathrm{CD}(5 \%)$ & & 3.80 & 0.32 & & 2.60 & 0.42 & \\
\hline
\end{tabular}

Growth and vigour of shoots- Poor +; Moderate ++; Good +++ : Mean \pm SE; Means followed by different letters in the same column differ significantly at $p=0.05$ according to Duncan's multiple range test).

Table 3. Effect of different concentrations of NAA and commercial sugar on root induction in sugarcane varieties Co86032 and CoC671.

\begin{tabular}{|c|c|c|c|c|c|c|c|c|}
\hline \multirow{2}{*}{$\begin{array}{l}\text { Media } \\
\text { No. }\end{array}$} & \multicolumn{2}{|c|}{$\begin{array}{r}\text { 1/2 strength } \\
\text { MS Medium }\end{array}$} & \multicolumn{3}{|l|}{ Co86032 } & \multicolumn{3}{|l|}{ CoC671 } \\
\hline & $\begin{array}{l}\text { NAA } \\
(\mathbf{m g} / \mathbf{L})\end{array}$ & $\begin{array}{l}\text { Sugar } \\
(\%)\end{array}$ & $\begin{array}{l}\% \text { rooting } \\
\text { of shoots }\end{array}$ & $\begin{array}{l}\text { No. of roots } \\
\text { per shoot }\end{array}$ & $\begin{array}{l}\text { Root length } \\
(\mathrm{cm})\end{array}$ & $\begin{array}{l}\text { \% rooting } \\
\text { of shoot }\end{array}$ & $\begin{array}{l}\text { No. of roots } \\
\text { per shoot }\end{array}$ & $\begin{array}{l}\text { Root length } \\
(\mathrm{cm})\end{array}$ \\
\hline $\mathrm{R} 1$ & 4.0 & 4.0 & $46.67 \pm 6.67^{c}$ & $3.75 \pm 0.13^{c}$ & $1.75 \pm 0.09^{\mathrm{e}}$ & $35.56 \pm 5.88^{c}$ & $3.20 \pm 0.17^{\mathrm{e}}$ & $1.39 \pm 0.11^{\mathrm{e}}$ \\
\hline $\mathrm{R} 2$ & 5.0 & 4.0 & $57.78 \pm 4.45^{\mathrm{bc}}$ & $4.50 \pm 0.47^{\mathrm{bc}}$ & $2.26 \pm 0.25^{\mathrm{cd}}$ & $44.44 \pm 8.01^{\mathrm{bc}}$ & $4.31 \pm 0.16^{\mathrm{cd}}$ & $1.61 \pm 0.20^{\mathrm{de}}$ \\
\hline $\mathrm{R} 3$ & 6.0 & 4.0 & $62.22 \pm 5.88^{\mathrm{bc}}$ & $5.36 \pm 0.48^{\mathrm{b}}$ & $2.41 \pm 0.09^{c}$ & $51.11 \pm 8.01^{\mathrm{abc}}$ & $4.80 \pm 0.31^{\mathrm{bc}}$ & $1.99 \pm 0.07^{\mathrm{cd}}$ \\
\hline R5 & 5.0 & 5.0 & $84.44 \pm 5.88^{a}$ & $8.49 \pm 0.25^{\mathrm{a}}$ & $3.87 \pm 0.12^{a}$ & $71.11 \pm 5.88^{\mathrm{a}}$ & $6.01 \pm 0.66^{\mathrm{a}}$ & $3.09 \pm 0.13^{\mathrm{a}}$ \\
\hline R6 & 6.0 & 5.0 & $75.55 \pm 2.22^{\mathrm{ab}}$ & $8.16 \pm 0.21^{\mathrm{a}}$ & $3.42 \pm 0.08^{b}$ & $64.44 \pm 5.88^{\mathrm{ab}}$ & $5.80 \pm 0.33^{\mathrm{ab}}$ & $2.89 \pm 0.19^{\mathrm{ab}}$ \\
\hline R7 & 4.0 & 6.0 & $64.44 \pm 5.88^{\mathrm{bc}}$ & $4.78 \pm 0.28^{b c}$ & $2.53 \pm 0.09^{c}$ & $53.33 \pm 3.85^{\mathrm{abc}}$ & $3.70 \pm 0.28^{\mathrm{de}}$ & $2.45 \pm 0.28^{b c}$ \\
\hline $\mathrm{R} 8$ & 5.0 & 6.0 & $73.33 \pm 6.67^{\mathrm{ab}}$ & $4.98 \pm 0.29^{b c}$ & $2.58 \pm 0.21^{\mathrm{c}}$ & $62.22 \pm 8.01^{\mathrm{ab}}$ & $4.53 \pm 0.26^{\mathrm{cd}}$ & $2.60 \pm 0.20^{\mathrm{ab}}$ \\
\hline
\end{tabular}

$($ Mean \pm SE); Means followed by different letters in the same column differ significantly at $p=0.05$ according to Duncan's multiple range test. 
Table 4. Effect of different concentrations of IBA and commercial sugar on root induction in sugarcane varieties Co86032 and CoC671.

\begin{tabular}{|c|c|c|c|c|c|c|c|c|}
\hline \multirow[t]{2}{*}{$\begin{array}{l}\text { Media } \\
\text { No. }\end{array}$} & \multicolumn{2}{|c|}{$\begin{array}{l}1 / 2 \text { strength MS } \\
\text { medium }\end{array}$} & \multicolumn{3}{|l|}{ Co86032 } & \multicolumn{3}{|l|}{ CoC671 } \\
\hline & $\begin{array}{l}\text { IBA } \\
(\mathrm{mg} / \mathrm{L})\end{array}$ & $\begin{array}{l}\text { Sugar } \\
(\%)\end{array}$ & $\begin{array}{l}\% \text { rooting } \\
\text { of shoots }\end{array}$ & $\begin{array}{l}\text { No. of roots } \\
\text { per shoot }\end{array}$ & $\begin{array}{l}\text { Root length } \\
\text { (cm) }\end{array}$ & $\begin{array}{l}\text { \% rooting } \\
\text { of shoot }\end{array}$ & $\begin{array}{l}\text { No. of roots } \\
\text { per shoot }\end{array}$ & $\begin{array}{l}\text { Root length } \\
\text { (cm) }\end{array}$ \\
\hline $\mathrm{R} 1$ & 4.0 & 4.0 & $44.44 \pm 5.88^{c}$ & $3.37 \pm 0.07^{\mathrm{e}}$ & $1.61 \pm 0.15^{\mathrm{e}}$ & $42.22 \pm 4.45^{\mathrm{c}}$ & $3.53 \pm 0.04^{\mathrm{e}}$ & $2.00 \pm 0.25^{\mathrm{d}}$ \\
\hline $\mathrm{R} 2$ & 5.0 & 4.0 & $51.11 \pm 5.88^{b c}$ & $3.99 \pm 0.14^{\mathrm{cd}}$ & $2.16 \pm 0.30^{\text {cde }}$ & $55.56 \pm 4.44^{\mathrm{bc}}$ & $4.72 \pm 0.19^{\text {cde }}$ & $2.22 \pm 0.16^{\mathrm{cd}}$ \\
\hline R4 & 4.0 & 5.0 & $62.22 \pm 2.22^{\mathrm{ab}}$ & $5.12 \pm 0.23^{b}$ & $3.15 \pm 0.13^{\mathrm{ab}}$ & $68.89 \pm 5.88^{\mathrm{ab}}$ & $5.40 \pm 0.44^{b c}$ & $3.41 \pm 0.46^{\mathrm{ab}}$ \\
\hline R5 & 5.0 & 5.0 & $73.33 \pm 3.85^{\mathrm{a}}$ & $6.32 \pm 0.19^{\mathrm{a}}$ & $3.45 \pm 0.15^{\mathrm{a}}$ & $82.22 \pm 5.88^{a}$ & $6.72 \pm 0.48^{a}$ & $3.99 \pm 0.29^{a}$ \\
\hline R6 & 6.0 & 5.0 & $66.66 \pm 6.67^{\mathrm{ab}}$ & $6.14 \pm 0.24^{\mathrm{a}}$ & $3.27 \pm 0.15^{\mathrm{a}}$ & $73.33 \pm 6.67^{\mathrm{ab}}$ & $6.40 \pm 0.60^{\mathrm{ab}}$ & $3.55 \pm 0.35^{\mathrm{ab}}$ \\
\hline R7 & 4.0 & 6.0 & $55.56 \pm 5.88^{b c}$ & $3.59 \pm 0.10^{\mathrm{de}}$ & $2.47 \pm 0.29^{\mathrm{cd}}$ & $60.00 \pm 10.18^{b c}$ & $3.80 \pm 0.15^{\mathrm{de}}$ & $2.93 \pm 0.31^{b c}$ \\
\hline \multicolumn{3}{|c|}{$\mathrm{CD}(5 \%)$} & 13.04 & 0.55 & 0.62 & 15.18 & 1.22 & 0.89 \\
\hline
\end{tabular}

(Mean \pm SE); Means followed by different letters in the same column differ significantly at $p=0.05$ according to Duncan's multiple range test.

Effect of different concentrations of IBA or NAA and commercial sugar on root induction in sugarcane varieties Co86032 and CoC671

The regenerated shoots were used for root induction in the root forming media. The rooting response of in vitro regenerated shoots was tested on half strength MS basal medium supplemented with different concentrations of NAA or IBA (4-6mg/L) with commercial sugar (4-6\%) Among all combinations of NAA and commercial sugar, variety Co86032 showed the highest rooting frequency $(84.44 \%)$ with an average root number per shoot (8.49) and root length $(3.87 \mathrm{~cm})$ on half $\mathrm{MS}$ medium supplemented with NAA $(5.0 \mathrm{mg} / \mathrm{L})$ and $5 \%$ commercial sugar. When higher concentration of NAA $(6.0 \mathrm{mg} / \mathrm{L})$ was used at same sugar concentration $(5 \%)$ there was decrease in rooting in Co86032 (75.55\%) (Table 3).

On the other hand variety CoC671 showed the maximum rooting response $(82.22 \%)$ with an average root number per shoot (6.72) and root length $(3.99 \mathrm{~cm})$ on half MS medium supplemented with IBA $(5.0 \mathrm{mg} / \mathrm{L})$ and $5 \%$ commercial sugar (Table 4). At higher concentration of NAA or IBA $(6.0 \mathrm{mg} / \mathrm{L})$ and commercial sugar $(6.0 \%)$ shoots became stunted, leaves became curved and roots were brownish in colour. While on medium containing NAA or IBA (4-6 mg/L) the best rooting response was observed with 5\% commercial sugar. The current results agree with other in vitro root induction reports on sugarcane. Yadav et al. (2012) recorded better rooting when in vitro shoots were inoculated on the half strength MS basal media with NAA $(5.0 \mathrm{mg} / \mathrm{L})$ and sucrose (5\%). Baksha et al. (2002) used NAA (5.0 $\mathrm{mg} / \mathrm{L}$ ) for best response of rooting in half strength MS medium. Many workers also reported that NAA $(5 \mathrm{mg} / \mathrm{L})$ was good for rooting (Shukla et al., 1994; Gosal et al., 1998; Lal et al., 2001) and more than NAA $(5 \mathrm{mg} / \mathrm{L})$ inhibits rooting. Alam et al. (2003) reported best rooting with IBA $(2.5 \mathrm{mg} / \mathrm{L})$ Khan et al. (2006) stated that the types and concentrations of auxin/s in the rooting media influenced the root induction response of sugarcane varieties.

Mekonnen et al. (2014) reported that on half MS medium with $6 \%$ table sugar, IBA $(2.5 \mathrm{mg} / \mathrm{L})$ induced the highest rooting response and root number in genotype Co449 while NAA $(5.0 \mathrm{mg} / \mathrm{L})$ gave the maximum rooting with highest number of roots per shoots in genotype Co678. They also recorded that shoot multiplication and rooting response on sucrose or table sugar supplemented media are not significantly different. In the present study shoot multiplication and rooting response have been tested only on commercial sugar which is relatively cheaper carbon source as compared to sucrose. 

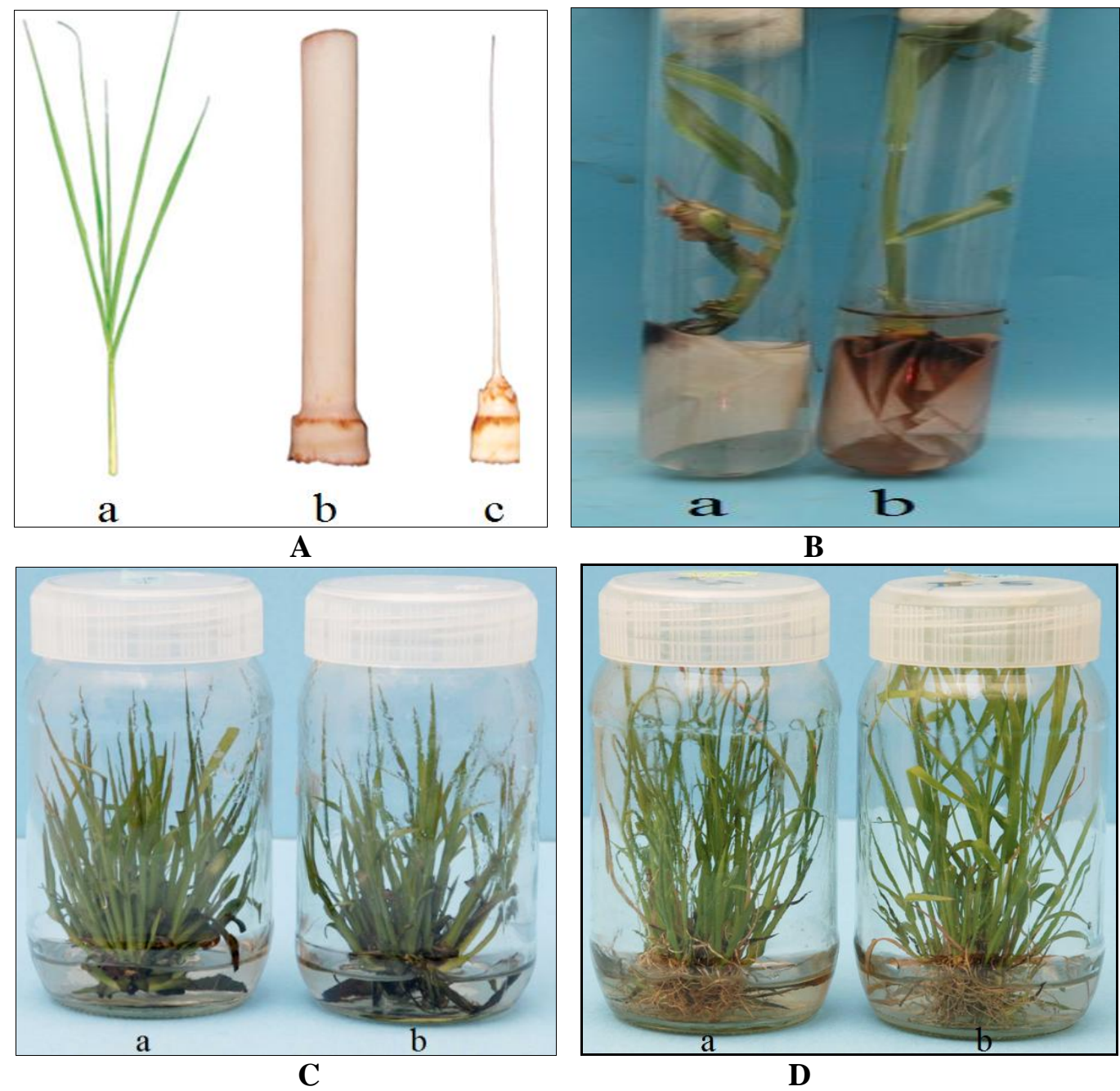

Fig. 1: A - a, b - Explant preparation, c - Apical meristem, B - a - In vitro growth of apical meristem of variety Co86032 with BAP $(0.2 \mathrm{mg} / \mathrm{L})$ and kinetin $(0.1 \mathrm{mg} / \mathrm{L}), \mathrm{b}-$ In vitro growth of apical meristem of variety CoC671 with kinetin $(0.5 \mathrm{mg} / \mathrm{L}), \mathbf{C}-\mathrm{a}-$ In vitro shoot multiplication of variety Co86032 with BAP $(0.2 \mathrm{mg} / \mathrm{L})$ and kinetin $(0.1 \mathrm{mg} / \mathrm{L})$, b In vitro shoot multiplication of variety CoC671 with BAP $(0.2 \mathrm{mg} / \mathrm{L})$ and kinetin $(0.2 \mathrm{mg} / \mathrm{L}), \mathbf{D}-$ In vitro rooting of variety Co86032 with NAA $(5 \mathrm{mg} / \mathrm{L})$ \& commercial sugar 5\%, b - In vitro rooting of variety CoC671 with IBA (5mg/L) and commercial sugar $5 \%$.

The economics of the two methods viz., (i) autoclaving of media and (ii) using sodium hypochlorite as a media sterilant was worked out. The present production capacity of Tissue Culture Laboratory at Vasantdada Sugar Institute is 1.0 million plantlets per year and on this basis the economics has been worked out. It was observed that for production of 1.0 million plantlets, electricity consumption worth Rs. 0.3 million was required for autoclaving. This comes to Rs 0.3per plantlet. If on the other hand sodium hypochlorite was used for sterilizing media the cost of sodium hypochlorite comes to Rs. 600 for production of 1.0 million plantlets. This cost is negligible. Thus about Rs. 0.3 million can be saved on electricity bills per year.
For the production capacity of 1.0 million plantlets per year if sucrose is used in all media, sucrose of Rs.0.2 million will be required. This comes to Rs.0.2 per plantlet. On the other hand if commercial sugar is used in all media excluding the initiation medium the cost of commercial sugar comes to Rs. 15000 per year for production of 1.0 million plantlets. It comes to Rs. 0.015 per plantlet.

\section{Conclusion}

From the present studies, it is concluded that micropropagation of sugarcane is dependent on the genotypes of mother plant and the phytohormone 
combinations used in different media. For every variety, response to different phytohormone combinations is different as far as rapid shoot initiation, shoot multiplication and root induction is considered. Variety Co86032 showed maximum shoot formation on MS medium supplemented with BAP and Kinetin while variety CoC671 showed maximum shoot formation on MS medium supplemented with Kinetin only. The best response in terms of shoot multiplication for variety Co86032 was observed on MS medium with BAP $(0.2 \mathrm{mg} / \mathrm{L})$ and Kinetin $(0.1 \mathrm{mg} / \mathrm{L})$ while for variety CoC671 best response was observed on MS medium with Kinetin and BAP $(0.2 \mathrm{mg} / \mathrm{L}$ each $)$ and $3.0 \%$ commercial sugar. . Half strength MS basal medium with NAA and commercial sugar induced highest rooting in Co86032. While in variety CoC671, half strength MS basal medium with IBA and commercial sugar induced highest rooting. In the present study all culture media (shoot initiation, shoot multiplication and rooting) were used in liquid state instead of semi solid agar media. This increased the survival rate under green house condition.

The shoot initiation medium was only sterilized by conventional autoclaving method while all other media including shoot multiplication and rooting were chemically sterilized by using chemical sterilant Sodium hypochlorite $(\mathrm{NaOCl})$. The study also revealed that use of commercial sugar can effectively replace the use of expensive sucrose in in vitro multiplication of sugarcane varieties. Use of liquid media, chemical sterilant $\mathrm{NaOCl}$ and commercial sugar helped in reducing the cost per plantlet to a considerable extent.

\section{Conflict of interest statement}

Authors declare that they have no conflict of interest.

\section{References}

Alam, R., Mannan, S.A., Karim, Z., Amin, M.N., 2003. Regeneration of sugarcane (Saccharum officinarum L.) plantlet from callus. Pak. Sugar J. 18, 15-19.

Ali, A., Iqbal, J., Naz, S., Siddiqui, F.A., 2008. An efficient protocol for large scale production of sugarcane through micropropagaton. Pak. J. Bot. 40(1), 139-149.

Ali, K., Afghan, S., 2001. Rapid multiplication of sugarcane through micropropagation technique. Pak. Sugar J. 16(6), 11-14.

Anita, P., Jain, R.K., Schrawat, A.R., Punia, A., 2000. Efficient and cost effective micropropagation of two early maturing varieties of sugarcane (Saccharum spp.). Indian Sugar. 50, 611-618.

Anonymous, 2015. Cooperative Sugar Report Nov.2015. 47, 3.

Baksha, R., Alam, R., Karim, M.Z., Paul, S.K., Hossain, M.A., Miah, M.A.S., Rahman, A.B.M.M., 2002. In vitro shoot tip culture of sugarcane (Saccharum officinarum) variety LSD28. Biotechnol. 1(2-4), 67-72.

Cheema, K.L., Hussain, M., 2004. Micropropagation of sugarcane through apical bud and axillary bud. Int. J. Agric. Biol. 2, 257-259.

Gosal, S.S., Thind, K.L., Dhaliwal, H.S., 1998. Micropropagation of sugarcane. An efficient protocol for commercial plant production. Crop Improv. 2, 167-171.

Hendre, R.R., Iyer, R.S., Kotwal, M., Khupse, S.S., Mascarenhas, A.F., 1983. Rapid multiplication of sugarcane by tissue culture. Sugarcane. 1, 4-9.

Khan, I.A., Dahot, M.U., Yasmin, S., Khatri, A., Seema, N., Naqvi, M.H., 2006. Effect of sucrose and growth regulators on the micropropagation of sugarcane clones. Pak. J. Bot. 38(4), 961-967.

Khan, S.A., Rashid, H., Chaudhary, M.F., Chaudhary, Z., Fatima, Z., Siddiqui, S.U., Zia, M., 2009. Effect of cytokinins on shoot multiplication in three elite sugarcane varieties. Pak. J. Bot. 41(4), 1651-1658.

Krishnamurthy, M., 1994. Alteration of conventional and unconventional means of breeding in sugarcane. Proc. SABRAO, XVIIth Int. Congr. and WSAA Symp. Held at academia Sinica, Nankang, Taipei, Taiwan, Nov.16-19, 1(35), 285-289.

Lal, M., Singh, B., Yadav, G.C., 2001. An efficient protocol for micropropagation of sugarcane using shoot tip explants. Sugar Tech. 3(3), 113-116.

Mekonnen, T., Diro, M., Sharma, M., Negi, T., 2014. Protocol optimization for in vitro mass propagation of two sugarcane (Saccharum officinarum L.) clones grown in Ethiopia. Afr. J. Biotechnol. 13(12), 1358-1368.

Murashige, T., Skoog, F., 1962. A revised medium for rapid growth and bioassay with tobacco cultures. Plant Physiol. 15, 473-497.

Singh, N., Kumar, A., Garg, G.K., 2006. Genotype dependent influence of phytohormone combination and subculturing on micropropagation of sugarcane varieties. Ind. J. Biotechnol. 5(1), 99-106.

Pawar, S.V., Patil, S.C., Jambhale, V.M., Naik, R.M., Mehetre, S.S., 2002. Rapid multiplication of commercial sugarcane varieties through tissue culture. Indian Sugar. 52(3), 183-186.

Sawant, R.A., Tawar, P.N., 2011. Use of sodium hypochlorite as media sterilant in sugarcane micropropagation at commercial scale. Sugar Tech. 13(1), 27-35.

Sengar, K., 2010. Developing an efficient protocol through tissue culture technique for sugarcane micropropagation. Bio InfoBank. 18, 56. 
Shukla, R., Khan, A.Q., Garg, G.K., 1994. In vitro clonal propagation of sugarcane: Optimization of media and hardening of plants. Sugarcane 4, 21-23.

Sreenivasan, T. V., Sreenivasan, J., 1992. Micropropagation of sugarcane varieties for increasing cane yield. SISSTA Sugar J. 18, 61-64.

Tiwari, A.K., Mishra, N., Tripathi, S., Lal, M., Singh, R.K., Sharma, M.L., 2011. Assessment of genetic stability in micropropagated population of sugarcane variety $\mathrm{CoS}$ 07250 through SSR markers. Vegetos. 24(2), 75-80.

Yadav, S., Ahmad, A., Lal, M., 2012. Effect of different auxins and cytokinins on in vitro multiplication and rooting of shoot cultures in sugarcane. Int. J. Biol. Pharmaceut. Res. 3(6), 814-818.

\section{How to cite this article:}

Sawant, R. A., Meti, N.T., 2016. Cost effective techniques for in vitro propagation of two varieties of sugarcane. Int. J. Curr. Res. Biosci. Plant Biol. 3(5), 65-72.

doi: http://dx.doi.org/10.20546/ijcrbp.2016.305.010 